\title{
THE DUTY OF A DIRECTOR PURCHASING SHARES OF STOCK
}

\author{
CLARENCE D. LAYLIN \\ Professor of Law, Ohio State University.
}

It is true enough that "the life of the law has not been logic: it has been experience."1 Occasionally, however, one encounters a legal problem to which the judicial reactions when guided only by intuitions and prejudices have not been as nearly unanimous as they were, for example, in support of the rule of Price $v$. Neal. ${ }^{2}$ Such a situation seems to exist with respect to whether or not a director of a corporation for, profit negotiating with a stockholder for the purchase of the latter's shares owes him a duty to disclose, unsolicited, all material facts bearing upon their value which the former may have learned while a director.

Much has been written upon this theme. ${ }^{3}$ Indeed, the state of the legal literature of the subject precludes exhaustive analysis of the cases. It may be stated, however, that those who have written have affirmed the existence of the duty, and have put it upon the ground that the director sustains a fiduciary relation to the individual stockholder with respect to the shares of the latter. Yet, the current of

\footnotetext{
${ }^{2}$ Holmes, The Common Law, I.
}

${ }^{2}$ (1762) 3 Burr. I354; see Ames, The Doctrine of Price v. Neal (I8gr) 4 Harv. L. REv. 297; Lectures on Legal History, 270; Wigmore, A Summary of QuasiContracts (1891) 25 Axr. LAw. Rev. 695, 706; Keener, Quasi-Contracts, 154-8; Woodward, Quasi-Contracts, ch. V.; U. S. Bank v. Bank of Georgia (1825) to Wheat. 333, 355, per Mr. Justice Story; Dedham Nat. Bank v. Everett Nat. Bank (Igor) I77 Mass. 392, 395, per Holmes, J. In this instance a perfectly weilsettled rule has puzzled courts and commentators alike in the effort to find an analytical basis for it.

${ }^{3}$ W. W. Thornton, The Trust Relation between Corporate Officers and Stockholders Buying of, or Selling their Stock to Them (Ig08) 67 CENT. L. Jour. 452; Wilgus, Purchase of Shares of Corporation by a Director from a Shareholder (I9I0) 8 MICH. L. REv. 267-elaborately reviewing the then extant cases; A. H. Bigelow, The Relation of Directors of a Corporation to Individual Stockholders (I9I5) 8I Cent. L. Jour. 256; N. C. Collier, Liabilities of Directors and of Trustees to Beneficial Owners Compared (I9I2) 74 Cent. L. Jour. 360; I Story, Equity Jurisp. (I2th ed.) 225; 3 Thompson, Corporations, s. 4034; Taylor, Private Corporations, 692, n.; Purdy's Beach, Private Corporations, s. 737 a; Elliott, Private Corporations, s. 502.

To make such an analysis, except as to cases decided since I9ro and referred to in note 5 , infra, would indeed be a work of supererogation in view of Professor Wilgus' article. 
actual adjudication shows that their efforts have not yet produced more than a contrariety of judicial opinion. ${ }^{5}$

It is felt that, quite properly, perhaps, the proponents of the affirmative have intuitively assumed the existence of the fiduciary relation in question, ${ }^{6}$ and that the judges who have supported the negative, finding that their intuitions were otherwise, have rejected it as a premise. ${ }^{7}$ To be sure, there has been some effort to support the affirmative by means of principles to which further reference will be made. But the impression of the writer is that the position has been assumed on practical grounds, and rejected on like grounds; and that the supporting reasons have been props rather than foundations. However this may be, it is quite evident that the reasons which have been adduced in favor of the rule have not been convincing to those in whose view the

The existence of the fiduciary relation in question was denied in the following cases decided since IgIo: Bawden v. Taylor (Igr2) 254 Ill. $464,98 \mathrm{~N}$. E. 941; Bacon v. Soule (Igr2) ig Cal. App. 428, 126 Pac. 384; Steinfeld v. Nielsen (I9I4) I5 Ariz. 424, I39 Pac. 888, correcting, on rehearing (1909) I2 Ariz. 38I, roo Pac. ro94; Allen v. Hyatt (I9I4, Jud. Com. Privy Council) I7 Dom. L. R. 7, affirming 8 Dom. L. R. 79-special relation recognized; Gadsden v. Bennetto (rgr2) 5 Dom. L. R. 529, reversed, 23 Manitoba, 33, 9 Dom. L. R. 7r9, on ground of actual fraud; Shaw v. Cole Mfg. Co. (I915) I32 Tenn. 210, I77 S. W. 479, L. R. A. I916 B, 706; Haverland $v$. Lane (Ig16) 89 Wash. 557, I54 Pac. III8.

It was affirmed in Steinfeld $v$. Nielsen (original hearing) supra, Black $v$. Simpson (1913) 94 S. C. 312, 77 S. E. r023, semble; Dazuson v. National Life Ins. Co. (Ig16) I76 Iowa, 362,157 N. W. 929 , L. R. A. r916 E, 878; Jacquith v. Mason (rgI6) 99 Nebr. 509, I56 N. W. ro4I.

- "The adoption of this rule is essential to check and stop the many frauds [sic] that are daily perpetrated by corporate officers upon the stockholders of their companies. Equity and good conscience require it" Thornton, op. cit. 67 CENT. I. JouR. 452, 457 .

"That the director may take advantage of his position to secure the profits that all have won, offends the moral sense; no shareholder expects to be so treated by the director he selects; no director would urge his friends to select him for that reason; that the law yet allows him to do this, does more to discourage legitimate investment in corporate shares than almost anything else, and allows the fiction of the corporate entity to obstruct instead of advance justice." Wilgus, op. cit. MrCE. L. REv. 267, 297.

"The debate as to whether technically a fiduciary relation exists may ... go on, but a knowledge of the law is not required to enable one to appreciate the moral wrong perpetrated by a corporate officer in profiting by the ignorance of a stockholder by means of knowledge acquired by virtue of his position." Ladd,

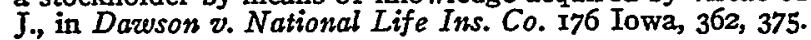

The following are believed to be fair examples of the expression of this view.

"It will not do to make the principle generally applicable to purchases by directors of the stock of their corporations.

"As to stocks which have a... market value, parties generally sell and buy them, with reference to this . value ....

"As to such stock, would it do to make the purchase of it by a director . . . an exception, and to say, that the parties dealt with reference to the real condition of the corporation and the supposed real value of the stock, founded on a ... supposed knowledge of its affairs? Plainly it would not; and plainly in such case, the application of the principle of equity would be unreasonable." Sutherland, J., in Carpenter v. Danforth (I868, N. Y.) 52 Barb. 58I, 586.

"The contrary view would place directors in a most invidious position, as they could not buy or sell shares without disclosing negotiations [to sell the undertaking], a premature disclosure of which might well be against the best interests of the company." Swinfen Eady, J., in Percival v. Wright [1902] 2 Ch. 42r, 426. 
practical aspects of the problem have suggested a negative answer. In this state of affairs it seems appropriate to apply analytical methods to the question and, though conscious of an intuitive preference for the affirmative rule, to endeavor to support that rule by reasons which may at least make the opposite result more difficult. A principle that is vindicated by logic is on that account more likely of acceptance than one which stands upon "felt necessities" alone-especially when all do not "feel" alike.

Is a director actually sub modo a trustee for each individual stockholder with respect to the latter's shares? It is submitted that the capacity of the stockholder to sue the directors in a proper case and, subject to certain restrictions, to restrain or redress a wrong against the corporation which incidentally affects the value of his shares ${ }^{8}$ does not establish such a relation. For in such cases his interests are derivative-he suffers through the corporation; while here the director's conduct does not affect the corporate assets in any way. Again, in those cases, all stockholders suffer alike; in these, none but the vendor of the shares can complain. So far, then, naught is established beyond obligations of the director to the corporation as such, that may be enforced by a single stockholder.

Is it, then, correct to assert at this point (as many have done) that the corporate personality-fictional or real, as one pleases-should be disregarded, and that the fiduciary relation which is admitted to exist between the directors and the corporation should as a result inure to the benefit of the individual stockholders, as the human beings screened behind the artificial entity ?10

It is believed that the solution of the problem must ultimately be worked out by disregarding the corporate "fiction;" but this particular application of the expedient is doubted. In the first place, it brings us no further on the way than to show that the director's agency which, as between him and the corporation, constitutes the particular fiduciary relation now sought to be extended to the stockholders, ${ }^{11}$ exists in rela-

\footnotetext{
${ }^{3}$ Robinson v. Smith (1832, N. Y.) 3 Paige, 222; Scott v. De Peyster (I832, N. Y.) I Edw. 513; Hodges v. New England Screw Co. (1850) I R. I. 3I2; Dodge v. Woolsey ( 1855, N. Y.) 18 How. 331 .

- See discussion of this point in Commissioners of Tippecanoe Co. v. Reynolds (1873) 44 Ind. 509, 516 et seq. This decision-a leading case on its side of the question-has been justly criticized; but the particular reasoning of Worden, J., therein, now referred to, is believed to be sound.

${ }^{10}$ Walsham v. Stainton (1863) I De G. J. \& S. 678; Oliver v. Oliver (1903) 118 Ga. 362, 367; Dawson v. National Life Ins. Co., supra.

"The inherently abstract idea of an artificial personality in the modern idea of a corporation, seems to form the ground of all this difficulty." Bigelow, $o p$. cit. 8I CENT. L. JouR. 256, 261. See excerpt from Professor Wilgus' article supra, n. 6; also passages quoted post, n. I2.

"Dawson v. National Life Ins. Co. 176 Iowa, 362, 387; Von Au v. Magenheimer (Ig08) I26 N. Y. App. Div. 257; Walsham v. Stainton, supra.
} 
tion to the whole body of the stockholders. The agent's real principal, if the juristic person be ignored, is a collection of individuals. This objection has apparently been felt by some supporters of the rule under discussion, and they seem to urge in reply that the emerging collection of individuals may be treated as a partnership, or at the least as a joint undertaking. So treating the association, its affairs are found to be controlled by a few managers who sustain fiduciary relations to each individual associate. ${ }^{12}$

In the second place, however, the-opponents of the rule have asserted that it is not enough to show a fiduciary relation as between the individual stockholders and the directors, but that it must also appear that the relation exists with respect to the shares owned by the former and that this is not the case. ${ }^{13}$ In other words, they say that the confidence reposed by the stockholders in the directors relates to the management of the business of the association and not to the separate affairs of particular members of it. If this point is sound, its validity as an objection to the rule is open to argument, but the expediency of questioning its soundness, if by such means it can be obviated, would seem to be apparent.

The two objections which have been mentioned are those usually put forward in opposition to the rule. It is believed, however, that there is another possible objection. The established principle is that the

${ }^{12}$ See the cases cited supra, n. II; Oliver v. Oliver, supra; Wilgus, op. cit. MxCH. L. REV.

"Whether the corporation be treated as an enlarged and amplified form of partnership and the director as managing partner, or whether he is called an agent or trustee elected by the stockholders to represent them in the management of the concern, he occupies a fiduciary position ... " Lamar, J., in Oliver v. Oliver, II8 Ga. 362, 369 .

"The fiduciary obligation is to the stockholders in a body. Why not to the component parts represented by the shares? . .

"Had that imaginary legal entity known as the corporation been regarded for the moment merely as an association of individuals investing different sums in a common enterprise, with the design of accomplishing specified purposes through those selected as directors, it would not have been so difficult to have understood the relation of confidence existing between director and shareholder." Ladd, J., in Dazeson v. National Life Ins. Co. I76 Iowa, $362,376,390$, supra.

${ }^{18}$ This seems to be the real or ultimate ground of decision in Carpenter v. Danforth, 52 Barb. 58I, supra, and Commissioners v. Reynolds, 44 Ind. 509, supra,the leading cases.

"There is, therefore, a certain trust relation between the shareholders and the directors of a corporation; but the trust put in the directors usually extends, and I must assume that in this case it extended only to the management of the general affairs of the corporation, with a view to dividends of profits... The directors are not trustees for the sale of the stock of the corporation .... I think it will be found, in most of the cases referred to by the counsel, that it appeared, or that it was assumed, that the trust, or trust relation, extended to the subject of the dealing, or contract in question. . . I I think that the sale or transaction, or its subject, is not so far connected with, or the subject of the trust, or trust relation which is admitted to exist, as to subject the director to ... the principle of equity ..." Sutherland, J., in Carpenter v. Danforth, 52 Barb. 58r, 584-6. Italics are the present writer's. See similar remarks of Worden, J., in Commissioners v. Reynolds, 44 Ind. 509, 516. 
existence of the corporation as a distinct entity is not to be ignored unless some paramount policy requires, or unless unconscionable results will follow its recognition in a particular case. ${ }^{14}$ The prevention of actual fraud is, of course, good ground for disregarding the corporate entity. ${ }^{15}$ But to do so on the principles thus far developed is to furnish a predicate for constructive fraud. This seems to be at least an exceptional use of the expedient of ignoring the corporate fiction. ${ }^{16}$ It is believed that the reasons for disregarding the corporate personality must exist independently; they must be actually present, concealed only by the corporate screen, so that its removal will reveal them. In the present case the removal of the screen results in creation rather than revelation.

It is believed that the true reason for the rule under discussion may be discovered without turning the corporation into a quasi-partnership, and in the first instance, without looking behind or through the corporate entity, but rather by looking directly at the corporate organization as it actually exists. The opposing arguments which have been mentioned have premised the proposition that a director is an agent.17

This proposition is inaccurate and in a sense untrue. Powers, duties and liabilities like those of an agent are cast upon the board of directors, it is true; but in almost all instances this devolution is the result of the important fact that directors are officers.

An officer is not merely one kind of agent or trustee. His representative authority is irrecusable-it springs from the law itself; the

"Salomon v. Salomon \& Co. Ltd. [I897] A. C. 22; Jackson v. Hooper (I909) I6 N. J. Eq. 592; U. S. v. Milwaukee Refrig. Trans. Co. (1905) r42 Fed. 247; Bank v. Trebein (1898) 59 Ohio St. 316; State v. Standard Oil Co. (1892) 49 Ohio St. I37; People v. North River Sugar Ref. Co. (189o) I2I N. Y. 582. Deference to the "fiction theory" would perhaps dictate another phrasing of the rule, such as that set forth in the opinion of Minshall, $J$., in State $v$. Standard Oil Co.:

"The general proposition that a corporation is to be regarded as a legal entity ... is a mere fiction, existing only in idea. ... It has been introduced for the convenience of the company ... but where it is urged to an end subversive of its policy, or such is the issue, the fiction must be ignored. . ..." 49 Ohio St. 137, 177, 179.

As to the fundamental nature of a corporation, see the article by Professor Wesley N. Hohfeld on Nature of Stockholders' Individual Liability for Corporationt Debts (I909) 9 Columbia L. REv. 285, footnote 289-290.

Whether we say that the entity is to be regarded unless reasons for ignoring it appear, or that it is to be ignored unless the facts show occasion for its use as a legal fiction, the question as to what shall be the occasion for its use or its rejection remains open.

${ }^{15}$ U. S. v. Milwaukee Refrig. Trans. Co. I42 Fed. 247, supra; Bank v. Trebein, 59 Ohio St. 3r6, supra; Brundred v. Rice (1892) 49 Ohio St. 540; Montgomery Web Co. v. Deinelt (1890) I33 Pa. St. 585; Linn Timber Co. v. U. S. (I915) 236 U. S. 574.

${ }^{16}$ Cf. Salomon v. Salomon \& Co. Ltd. [1897] A. C. 22, supra.

${ }^{17}$ See supra, notes II, 12 and I3. 
powers of the agent or trustee are consensual. The agent is his principal's alter ego within the scope of his authority; the officer is, in reality, the principal itself, pro hac vice. The officer, whether public or corporate, is one in whom the law vests power to determine the public or corporate action in an independent capacity. ${ }^{18}$

An office is a thing of which legal title can be predicated. ${ }^{10}$ Not so with an agency. Not so, either, with a trusteeship, which results from a qualified legal title, but is not itself a subject of title. Aside from the mere name, what, then, is there of substance in an office that it should be capable of being held in possession and susceptible to a right to possession? Manifestly, no more than a group of inherent and independent powers. ${ }^{20}$ These, however, vest in the officer for the benefit of others, not for his own benefit. Accordingly, the officer is in a real sense a trustee of his official powers. ${ }^{2 x}$

The trust relation thus established is to be sure an imperfect one. It lays the foundation of few if any rights cognizable in a court of equity and hence it may at once be conceded to lack the essential characteristics of a technical trust. But it is a trust sub modo and it satisfies every element of a perfect trust save one.

The identity of the cestui que trustent sub modo of the powers of the directors of a private corporation depends upon the particular power in question. In many, perhaps most instances, the corporate "person" itself is regarded as the one to which the obligation is due. ${ }^{22}$ In several if not all of these instances, it is believed that the prevailing conception is inaccurate save in a qualified sense. We need not stop to consider the general question thus suggested in all its broader aspects; a single power will suffice for present purposes. Let us take the power to declare dividends. It is certainly not to be exercised for the benefit of

"Hoyt v. Thompson (1859) Ig N. Y. 207, 216, per Comstock, I.; People v. Powell (I9II) 201 N. Y. I94; Charlestown Boot \& Shoe Co. v. Dunsmori (I880) 60 N. H. 85; Automatic Self-Cleaning Filter Co. v. Cunninghame [1g06] 2 Ch. 34. See article by W. P. Rogers, Corporations (I9r5) 60 OHro L. Bull. 20r, 47 Chic. L. News, 382.

${ }^{10}$ While no modern American case has been found which expressly establishes this point, those involving questions of extraordinary remedies are full of such expressions as "the question of title to an office" and "possession of an office." See People v. Police Commissioners (1903) 174 N. Y. 450, the reasoning in which is applied to the case of a director of a private corporation in People v. Powell, 201 N. Y. 194, supra. It is believed that, in the sense in which the terms "title" and "possession" are herein used, their employment in such connections is correct.

${ }^{20}$ Opinion of the Judges (I822, Me.) 3 Greenl. 48I; Matter of Hathaway (1877) 7 I N. Y. 238, 243; 2 Bl. Com. 36.

21 "It appears that, of the various powers which are given to them [directors] they are, in the strictest sense, trustees." Anon., The Fiduciary Position of Directors, 80 L. T. 299, 300. Italics are the present writer's.

${ }^{22}$ See supra, notes 8,12 and 13 . The cases declaring the existence of a trust relation between the directors and the corporation as such are, of course, numerous. 
the corporation as a distinct person, for when a dividend is once declared the corporation owes it to the entitled stockholders in severalty. ${ }^{23}$ In this situation the corporation cannot be thought of as a fiction representing the associated members. Suppose we disregard the corporate personality: what human beings are behind the screen when the corporation is subject to suit for dividends? It cannot be the stockholders, for they are the potential plaintiffs, and it would not do to say that they are about to sue themselves. Is it not the directors, who are the real persons in default? Indeed, it is believed to be a sound principle that whenever corporate conduct is in question and the character of the management and control of a corporation is consequently drawn in issue, the human beings discovered behind the fiction of corporate personality are more likely to be the managers than the members. ${ }^{24}$ It has frequently been somewhat carelessly assumed that to ignore the fiction means to recognize the stockholders as the real parties in interest; but obviously this is not always true, and the most recent cases recognize the exceptions.

If the power to declare dividends is not to be exercised for the benefit of the corporation it must exist for the benefit of the stockholders; and inasmuch as they do not appear here as the constitutents of the juristic person who is their theoretical adversary, they must be cestuis que trustent sub modo in their several and individual capacities. Therefore, in at least this one instance, the directors are fiduciaries of the individual stockholders.

Of course the power under discussion is discretionary and save in exceptional cases its exercise cannot be controlled by compulsory process. $^{25}$ Yet at the least, the income of the corporation and the enhance-

Hence the rule that dividends belong to the owner of the share at the time they are declared. Cates v. Consolidated Realty Co. (IgI4) 25 Cal. App. 53I, I44 Pac. 30I; Redhead v. Iowa Nat. Bank (I905) I27 Iowa, 572, I03 N. W. 796; Price v. Morning Star Mining Co. (I900) 83 Mo. App. 470; Tepfer v. Ideal Gas \& Elec. Fix. Co. (1908) 58 Misc. 396, rog N. Y. Supp. 664; Wallin v. Johnsond City Lumber \& $M f g$. Co. (Ig16, Tenn.) I88 S. W. 577, L. R. A. I917 B, 325. The fixation of the identity of those who are entitled to dividends as of a certain date demonstrates that their rights are several, and not enjoyed as members of the corporate body. Indeed, they are creditors of the corporation. Beers v. Bridgeport Spring Co. (1875) 42 Conn. 17; King v. Paterson I. H. R. R. Co. (186I) 29 N. J. L. 304. Cf. Ford v. Easthampton Rubber Thread Co. (1893) 158 Mass. 84; McLaran v. Crescent Planing Mill Co. (Ig06) II7 Mo. App. 49.

"See Daimler Co. v. Continental Tyre \& Rubber Co. [IgI6] 2 A. C. 307, 340, per Lord Parker of Waddington; Fritz Schulz Co. v. Rainier (Ig17) I66 N. Y. Supp. 567; Purchase v. Atlantic Safe Deposit Co. (1913) 81 N. J. Eq. 344, 346; Wilson v. U. S. (IgII) $22 \mathrm{I}$ U. S. $36 \mathrm{I}, 376$.

${ }^{2}$ Pratt v. Pratt, Reed \& Co. (1866) 33 Conn. 466; Williams v. Telegraph Co. (1883) 93 N. Y. I62; $M c N a b$ v. $M c N a b$ \& Harlin $M f g$. Co. (I89I, N. Y.) 62 Hun, 18. Cf. Scott v. Eagle Fire Ins. Co. (1838, N. Y.) 7 Paige, 203; Crichton v. Webb Press Co. (I904) Ir3 La. I67; Blanchard v. Prudential Ins. Co. (I9II) 78 N. J. Eq. 47 I. 
ment of the value of its property beyond the aggregate par value of its- shares, constitute assets which the directors can turn into only a limited number of possible channels. Dividends; surplus and reserve; extensions, betterments and advertising: these are the options which are offered. The choice of the first results in direct pecuniary benefit to stockholders as individuals; that of the second adds to the funds of the corporation as such, and if that entity be diregarded, to the assets of the stockholders as a body, and so-at least indirectly-to the value of all the shares and of each of them representing interests in the corporate assets; that of the third makes an investment of funds that might otherwise have been distributed among the stockholders, with a view to larger distributions in the future. Such a power of umpirage between the stockholders as distributees and the same persons as substantial co-owners would seem, clearly enough, to be one in which the latter as individuals have a beneficial interest. ${ }^{28}$ Even if we regard the individual stockholder as distinct from all the stockholders as a body, we arrive at the same result; for a trustee of powers which may be exercised for the benefit of either of two is a fiduciary as to both. ${ }^{27}$

The relation thus established is one which affects the shares belonging to the stockholder. Indeed, his investment has been made upon the faith of the beneficial exercise of the power. Many statutes use the phrase "for profit" or its equivalent to distinguish business companies from charitable corporations. The real meaning of such words is suggested by the paraphrase "for the purpose of securing dividends to its stockholders;" for the power to distribute profits, rather. than the capacity to reap them, is the distinguishing characteristic of a business company. ${ }^{28}$ Hence it appears that the securing of profits to the stockholders as investors is in law as well as in common understanding of the essence of the corporate purpose. Manifestly, also, it is an essential element in the concept of property involved in a share of stock. ${ }^{20}$ Therefore the fiduciary relation between the directors and the individual stockholders, growing out of the official powers of the former, is one that exists in respect of the shares of the latter.

\footnotetext{
$x$ "The directors and managing officers occupy the position of quasi trustees towards the stockholders . . . with respect to their shares of stock. Since the stockholders own these shares, and since the value thereof and all their rights connected therewith, are affected by the conduct of the directors, a trust relation plainly exists between the stockholders and the directors, which is concerned with and confined to the shares of stock held by the stockholders. . " 3 Pomeroy, Eq. Jurisp. (3d ed.) s. I090; cited with approval in Oliver $v$. Oiver, II8 Ga. 362, and in Dazeson v. National Life Ins. Co. I76 Iowa, 362, 378.

${ }^{7} E$. g., the situation of a trustee when the equitable estate is divided between a tenant for life' and a remainderman. See Perry, 'Trusts, ch. XVIII.

${ }^{28}$ See Clark \& Marshall, Private Corporations, s. 33; Snyder v. Chamber of Commerce (I895) 53 Ohio St. I.

${ }^{27}$ Angell \& Ames, Corporations, s. 557 ; Taylor, Private Corporations, s. 567.
} 
It is unnecessary to look further, for with this point granted, the duty to disclose follows upon easily applied principles. ${ }^{30}$ It is believed that similar fiduciary relations might be established as growing out of other powers of the directors, or as following upon principles slightly different from the power to direct the application of the profits. The method of approach which has been employed is chosen because it seems to offer the most obvious demonstration of the character of the relations between stockholders and directors, rather than with the thought that it is the only one available.

The assumption seems correct that some such fiduciary relation must be established in order to support the rule that the director must disclose facts known to him which affect the value of the shares when negotiating with a stockholder for their purchase. Without it, there would be no more foundation for the duty to disclose unsolicited information to a stockholder than there would be for such a duty on the part of a director selling his own shares to an outsider. If a seller understands that the buyer is in a position to know more about the value of the subject of sale than he does, there is nothing morally or

\footnotetext{
"It is believed that the reasoning of the cases which reject the rule contended for goes astray at this point. See supra, n. 13.

"The directors of a corporation stand in a relation similar to that of trustees for the shareholders. . . . Their action affects the whole body of shareholders, beneficially or injuriously, in respect to dividends upon, or the value of, their stock.

"But stock in a corporation held by an individual is his own private property W. over which neither the corporation nor its officers have any control. ..." Worden, J., in Commissioners v. Reynolds, 44 Ind. 506, 514, 515.

It would seem that the leading decisions concede the principle that if a fiduciary relation exists, either (I) respecting the sale itself or (2) respecting the subject of the sale, the trustee is required to make disclosure; and that they effectively dispose of the first point by demonstrating that the relation between directors and stockholders does not concern the actual transaction of selling shares; but that they do not deal with the bearing of the fiduciary relation upon the shares themselves as the subject of the transaction.

On the other hand, the opinion of Lamar, J., in Oliver v. Oliver, supro, seems to place the stress where it belongs, and while not pursuing the analysis to the degree attempted in this paper, appears convincing upon the point now under consideration:

"If, then, any sort of trustees, they are necessarily subject to the obligations and restrictions which inhere in that relation, as to any property entrusted to them. ... How is it possible in principle to draw the line and say that while trustee for some purposes, he is not for others immediately connected therewith?" II8 Ga. $362,369,370$.

The following, from the opinion of Ladd, J., in Dazeson v. National Life Ins. Co., supra, is also suggestive of correct principles:

"Though the stockholders have no legal title to the property, ... their shares represent integral parts of the whole, the proportional shares of the dividend declared or to be declared, and of the net assets upon dissolution. . . To say, then, that a director . . . owes nothing to the shareholders, as such, is in effect declaring that, though acting as trustee of the entity, he is under no obligation with respect to its component parts. ..." I76 Iowa, 362,377 .
} 
legally wrong, according to present-day standards, in laying upon him the burden of making inquiry of the buyer, and in declaring that he assumes the risk involved in his own silence. The only element that can change the result is the existence of a fiduciary relation. It is hoped that the considerations which have been presented will at least be suggestive of reasons which may be employed to meet the apparent demand for an analytical basis for such a relation, and thereby to vindicate and secure adoption for the rule which grows out of it. 